\title{
UMA NOVA ESPÉCIE DE HETERONOTUS LAPORTE (HOMOPTERA, MEMBRACIDAE) ${ }^{1}$
}

\author{
Antonio José Creão-Duarte ${ }^{2}$ \\ Albino Morimasa Sakakibara ${ }^{3}$
}

\begin{abstract}
A NEW SPECIES OF HETERONOTUS LAPORTE (HOMOPTERA, MEMBRACIDAE). Heteronotus mourei, sp.n. is described from Conde, Paraiba, Brazil.

KEY WORDS. Heteronotus, Membracidae, Homoptera, Brazil
\end{abstract}

\section{Heteronotus mourei, sp.n.}

Figs. 1-5

Caracteres diagnósticos: Tegumento liso e brilhante, de coloração geral castanho-escura com manchas amareladas: na cabeça entre os ocelos e sobre o clípeo, lateralmente junto aos olhos; no pronoto, anteriormente, em forma de um V, lateralmente sobre os lóbulos pós-oculares passando sobre os ângulos umerais; duas transversas entre a elevação supra-escutelar e o nódulo proximal.

Processo posterior com o nódulo proximal ovóide, levemente maior que o distal, distintamente peciolado entre ambos. Macho com o nódulo distal maior que o proximal.

Medidas (em mm) Fêmea/Macho: Comprimento total 11,6/9,6; comprimento do pronoto 9,6/8,4; largura máxima da cabeça 3,4/3,0;

Tipo e localidade-tipo: Holótipo fêmea de Vale das Cascatas, Conde, Paraíba, 06-VI-1992, Creão-Duarte col. Parátipos: 5 fêmeas e 7 machos com os mesmos dados do holótipo. Os tipos estão depositados na Coleção de Entomologia Pe. J. S. Moure do Departamento de Zoologia da Universidade Federal do Paraná, exceto três parátipos machos e três fêmeas na coleção do Departamento de Sistemática e Ecologia da Universidade Federal da Paraíba.

Descrição. Holótipo fêmea. Cabeça triangular, mais larga que longa, de superfície lisa e brilhante, com faixas amareladas: lateralmente junto com os olhos e sobre os lóbulos supra-antenais e longitudinalmente no espaço entre os ocelos e sobre o clípeo. Olhos ovalados e salientes para os lados. Ocelos pequenos, situados logo abaixo da linha imaginária que passa pelo centro dos

1) Contribuição número 754 do Departamento de Zoologia, Universidade Federal do Paraná.

2) Departamento de Sistemática e Ecologia, Universidade Federal da Paraiba, 58059-900 João Pessoa, Paraíba.

3) Departamento de Zoologia, Universidade Federal do Paraná, Cx. Postal 19020, 81531-970 Curitiba, Paraná, Brasil. Bolsista do CNPq. 


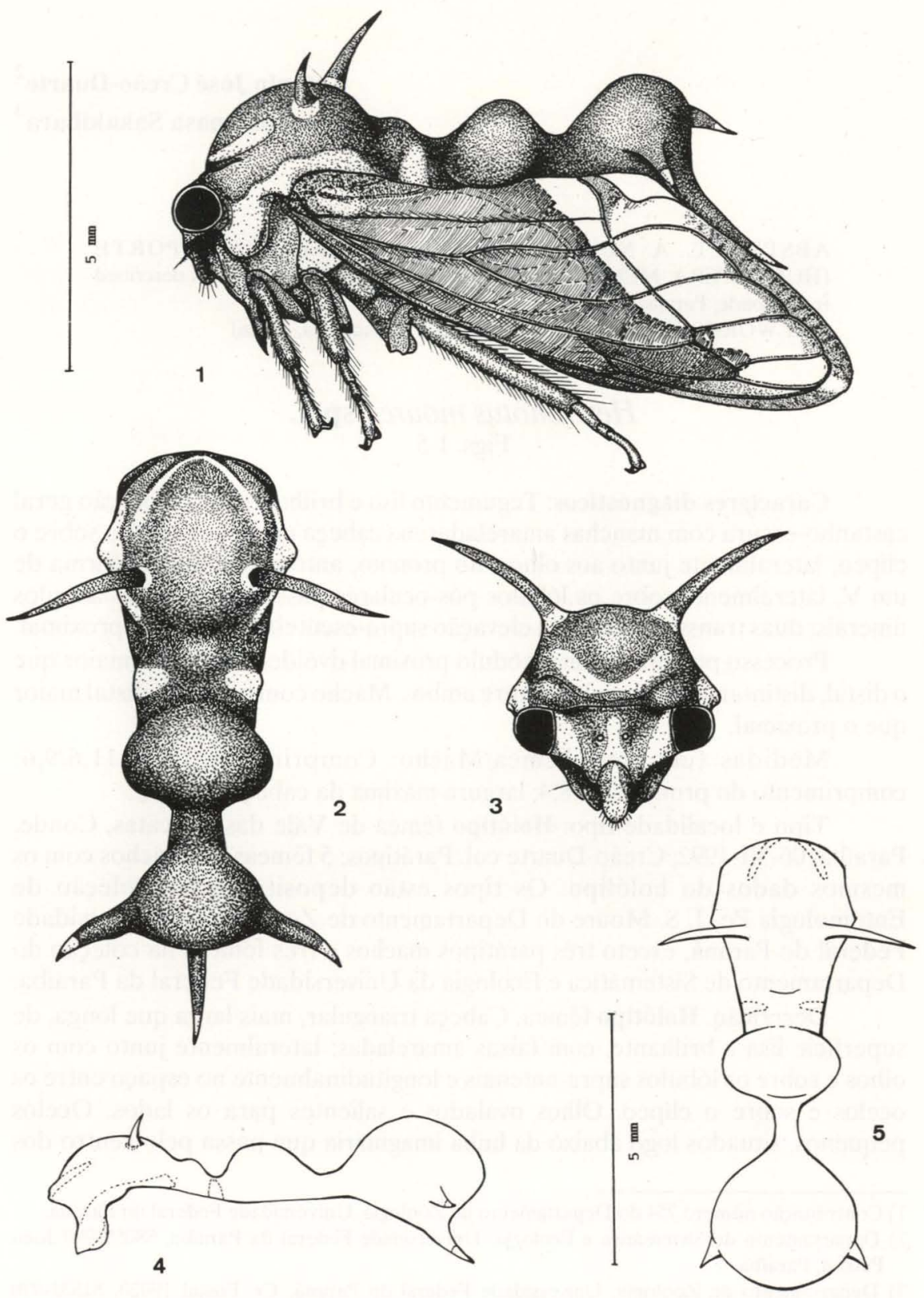

Figs 1-5. Heteronotus mourei, sp.n. (1-3) fêmea; (4-5) macho. 
olhos, mais próximos entre si do que dos olhos. Clípeo ovóide, pouco intumescido.

Pronoto liso e brilhante, de coloração castanho-escura, ornamentado com faixas amareladas: anteriormente sobre o metopídio em forma de um V com os braços quase atingindo a base dos processos supra-umerais; nas margens laterais desde os lóbulos até próximo a elevação supra-escutelar passando sobre ângulos umerais; transversalmente, de cada lado, entre a elevação supra-escutelar e o nódulo proximal; anel na base dos processos supra-umerais e anel pré-apical nos espinhos do nódulo distal. Processos supra-umerais finos, cônicos, de comprimento pouco inferior à largura da cabeça, divergentes e levemente curvos para trás. Elevação supra-escutelar obsoleta. Processo posterior distintamente binoduloso e bem junto das margens das tégminas; nódulo proximal ovóide, transverso; nódulo distal um pouco menor, arredondado, distintamente separado do anterior por um curto pecíolo, provido de três espinhos fortes, quase retos, o mediano pouco mais longo e mais robusto, paralelo e bem junto das tégminas, terminando na altura da quarta célula apical.

Tégminas hialinas, amarelo-âmbar, com as margens costal e apical e o ápice do clavo, escurecidos; uma pequena mancha clara na base, na altura da veia anal.

Tórax e pernas acastanhados, com exceção do mesepimero e faixas longitudinais irregulares nos fêmures médios e posteriores, amarelados. Abdômen acastanhado, com os segmentos genitais mais escuros.

Macho. Um pouco menor, com o nódulo distal arredondado e quase duas vezes maior que o proximal e com os espinhos mais curtos.

Planta hospedeira: Ingá (Leguminosae).

Comentário: Quanto à coloração geral e desenhos, forma e textura do pronoto, esta espécie segue o padrão de $H$. horridus (Fabricius, 1787). Aproxima-se muito de $H$. vandamei Boulard, 1980, com exceção do macho que tem o nódulo distal mais dilatado e os espinhos curtos.

\section{REFERÊNCIAS BIBLIOGRÁFICAS}

BOULARD, M. 1980. Missions Entomologiques en Guyane et au Brésil (I) Huitième note: Membracidae du genre Heteronotus. Revue fr. Ent. (N.S.) 2 (2): 53-68. 